By DOROTHY E. CHAMBERLAIN

\title{
In-Process Records
}

$\mathrm{O}$ NE OF THE PROBLEMS of a large cataloging department is to locate quickly books "in process" in the department. In a library where hundreds of books are received weekly and may be assigned to ten or fifteen catalogers, it is often difficult to locate wanted items and frequently searching for them involves a considerable expenditure of time on the part of one or possibly several catalogers. The only way to insure a quick and easy finding of any title, be it pamphlet, book, or serial publication, is to have a system of records for books in process which carries them from their arrival in the cataloging department to their departure for the shelves of the stacks or the department for which they are destined, and to keep this record until the catalog card is filed in the public catalog.

Such a record is also an aid to the acquisition department in checking orders to determine whether or not requests for purchase are duplicates of titles already in the library. In a large institution which contains many departmental libraries, several copies of one title may come in at intervals and each copy may be assigned to a different cataloger. The in-process file would list all copies and thus prevent unnecessary duplication of L.C. card orders or of mechanically reproduced cards.

The in-process record has not been considered at length by writers on cataloging department procedure-possibly because only in the last few years has the acquisition of new books in sufficient numbers made it difficult to locate titles in process. In Cannon's Bibliography of Library Economy there are two references in the index to "Process work." One is an article which described the use of process slips in the Public Library of the District of Columbia and in the Cambridge Public Library. In the former, the process slip was used in conjunction with the order department records and was destroyed as soon as the book was cataloged. In the latter, the process slip remained in the volume until it had gone through the various processes of preparation for the shelves, being initialed by each person who dealt with it, and then was filed in the catalog department and used to obtain the count of classified accessions for the month. The other reference is to an article by Henry A. Sharp, ${ }^{2}$ which is concerned with the routines through which books are supposed to go before reaching the clientele.

Library Literature contains no direct reference to in-process records and no mention of them is made by Akers, Bishop, or Irwin in their books on cataloging. Mann discusses briefly the waste of time in searching for books in process. ${ }^{3}$

Wyllis E. Wright, in his article "The Internal Organization of the Catalog Department," discusses the in-process catalog in use at the New York Public Library. There the order card is held as a record in the catalog department until the official catalog card is filed. Mr. Wright stresses the importance of records at each stage of the journey of material in the catalog depart-

\footnotetext{
1 Bulletin of Bibliography vol. 8, 1914.

2 Library World vol. 15 , 1913

3 Introduction to the Cataloging and Classification of Books. 2d ed. Chicago, American Library Association, 1943 , p. 238.

4 Randall, W. M., ed. The Acquisition and Catalog. ing of Books. Chicago, University of Chicago Press, 1940 .
} 
ment and says :

Accurate records of work done and of location of material at all times seems to me one of the fundamental needs in efficient organization. The time spent looking for the book which one is sure was on this shelf only yesterday, the time wasted because the staff member who had this is not in the room just now, the time and temper lost by a patron because a book in process cannot be found, are marks of bad management. On the other hand, we must beware of excess records, beyond the needs of the system. If there is sufficient material so that a single piece can be lost, or enough of a staff so that too many people have to be interrupted to find material, records of the position of the material in the department are necessary. ${ }^{5}$

In an effort to gather information concerning active process files, visits were made by the writer to four research libraries in New York City. Two of these, New York University and Teachers College, are not very large but they are research libraries, serving a clientele similar to that of the two larger institutions, Columbia University and the New York Public Library Reference Division. All four have a frequent demand for information about books in process.

The New York Public Library Reference Division, which catalogs annually forty thousand books and pamphlets in addition to fifty thousand serial volumes, holds some material in the department for two years before it reaches the shelves. The in-process catalog thus becomes a necessity. In this library there are three in-process filesone for documents, one for serials, and one for the general cataloging division, including personal authors or nonserial titles. The documents and serials in-process catalogs, in the main, follow the procedure of the general cataloging section, so a description of the processes of cataloging a book and the part the in-process catalog plays

5 Ibid., p. 131-32. will explain the system in sufficient detail. The order card or a similar card for a gift forms the basis for the in-process catalog. On the in-process card are recorded the author, title, imprint, source from which title was taken, dealer and date ordered, date received, date given to the cataloger and cataloger's initials, class mark, the temporary number assigned if the material is held in the department, an indication whether the material is to be bound, and the date the copy slip is sent to the printer. The books are arranged chronologically by date of receipt before going to the cataloger, so they can be found easily. For bound books published within the last two years, a temporary card is sent to the cata$\log$ and also to the divisional catalog if necessary when the book has been cataloged and sent to the shelf. It takes two or three weeks for cards to go through printing, and after the cards come back it may be six months before the headings are added to the cards and they are filed into the catalog. When the official catalog card is filed, the in-process card is removed and destroyed. Since there is a delay of some months in cards reaching the catalog, older books for which no temporary card is made can be located only by the in-process file. This seems to be a satisfactory system and as nearly foolproof as possible in a large library.

The cataloging department of the New York University Library, Washington Square, presents a great contrast in the size of its staff and the number of books it handles. About fifteen thousand books are cataloged yearly. In this library the order department sends two slips to the cataloging department when the book is ordered. One slip is used for the L.C. card order, and the other, stamped "L.C. cards ordered," placed in the book when received. While waiting for the L.C. response to the 
order, no card record is kept, but the books are alphabetically arranged on the shelves where they can be easily found. If there is to be a delay in obtaining L.C. cards, a temporary author card is filed in the public catalog and the book is held. If the book is sent on temporarily cataloged, as new books sometimes are, the "L.C. cards ordered" slip is placed in the L.C. order file, which forms an in-process catalog. Books for which L.C. cards cannot be obtained are promptly cataloged, and the cards are kept in alphabetical order until filed in the catalog so that a title can always be found. Temporary cards for important monographs and new open entries are put in the catalog. The official catalog and shelflist are in the catalog department and hence all records are accessible. With so small a number of books and cards going through fairly rapidly, books in process are not difficult to locate.

Teachers College Library handles about six thousand books a year. In addition to the regular order file in the acquisition department, which contains a card for each book ordered, stamped with the date of its receipt, a manifold of six slips is used. One of these slips goes to the dealer, one to the departmental library, and one is filed according to order number. A fourth slip is used as a temporary card in the public catalog, marked "ordered," and remains there until the cards are filed. Another slip is used as the order sent to Library of Congress. The remaining slip is filed in the L.C. outstanding order tray while waiting for L.C. cards, if the book is cataloged immediately. If the book is held in the cataloging department until L.C. cards come, the slip is kept with it. For gifts of recent publication date, a card is made and filed with the order cards in the acquisition department. No record is made for older books, which are kept together on the shelves until cataloged. With a small number of books and duplicate records at hand for all titles ordered, any book should be easily found in a department of this size.

The last cataloging department considered, that of Columbia University Libraries, is more nearly comparable with that of New York Public Library, although its book collection and staff are somewhat smaller-Columbia handles about twentyfour thousand new titles a year, not including the law or medical divisions and not counting serials. The documents and serials divisions both keep their own inprocess files, which are much more complete than that of the general cataloging division, but a description of the latter will suffice for this paper.

The Acquisition Department of the Columbia Libraries uses a nine-slip correlated order form, allocated as follows: Form I, record copy ; Form 2, bursar's copy ; Form 3, original purchase order; Form 4, outstanding order record; Form 5, Library of Congress card order; Form 6, departmental copy ; Form 7, rider copy (kept in outstanding order file until book arrives, then sent on with book) ; Form 8, claim copy; Form 9, supplementary slip (sent to cataloging department and kept there as a duplicate of the order sent to the Library of Congress). A separate file is kept of those items for which there is no order cardgifts, exchanges, and purchases en bloc. For these, two copies of the searcher's slip are made, one going to the cataloging department with the book, and the other put in the "Received Orders" file. The cataloging department retains these slips with the books, and subsequently, with the cards, through the card proofreading process, after which the slips are date-stamped and returned to the acquisition department. Since the return of the slip to that department is a signal that cards have reached 
the public catalog, the corresponding slip in the "Received Orders" file is removed, and both are discarded. If the book is sent to a departmental library for consideration, the slip is filed in a separate drawer marked "Offered to Libraries," until a departmental library indicates that it wants the item, when the slip is transferred to the "Received Orders" file and the book is sent to the cataloging department, after which the procedure follows the routine described above. If a title is put in the duplicate collection, a slip bearing a broad subject heading is placed in the book, and a duplicate slip is put in the file of "Duplicates."

This system ensures the prompt locating of a title in the acquisitions department, but the records kept in the cataloging department are by no means as complete, and once a book reaches there, it is not always found easily.

The in-process catalog for the general cataloging division, which was begun about six years ago, is not intended to be complete-it is mainly to cover the titles which remain in the cataloging department for some time. If the title is already in the Columbia catalog, the preliminary cataloger removes that card and puts it in the book, and if there is an L.C. card in the depository which is not in the Columbia catalog, he also puts that in the book and sends it on to the cataloger. If the cataloger completes work on the book at once, or plans to do so within a few days, a record, ordinarily either the searcher's duplicate slip or preliminary cataloger's work slip, with the addition of the cataloger's initials and the date, is put in the in-process file. This slip is necessarily removed when the cataloger proceeds to cata$\log$ the book, since it carries the information needed for cataloging. A temporary card is put in the catalog for all books for which L.C. cards are delayed, for all new books of any importance, and for older books if the subject or author seems to warrant it, while L.C. cards are going through the cataloging department. However, no temporary card, as a rule, is made for books for which cards are being typed or mimeographed. Hence, in many cases the only way to find a book after it is cataloged but before the cards reach the public catalog is through the shelflist and the trays of cards, alphabetically arranged, waiting to be handled by the typists.

It is interesting to note that three of these libraries use a duplicate of the order card, or the order card itself, as their inprocess records, thus avoiding unnecessary duplication of work. Of course, there is always the danger of the wrong entry on the order card not being caught when the book is cataloged under a different entry, but each of the cataloging departments tries to detect any such differences and note them on its in-process slips. Probably the ideal method is to put a temporary card in the public catalog for every title, but for a large library cataloging many thousands of books each year this would involve considerable time and money, and it is a question whether it would be worth while. The only sure way of locating a title quickly and easily in a large cataloging department is to keep a complete in-process record for every book or pamphlet in the general cataloging division until the cards are filed in the catalog. Catalogers are burdened with a great many records of varying usefulness, but probably most of them will agree that for any department handling thousands of books annually, an in-process catalog is a great timesaver. It need not be an added expense if a duplication of the order card or of the preliminary cataloger's work slip is used. In case of gifts and exchanges, the use of forms which provide at one typing slips for L.C. card orders and temporary records is suggested. 